\title{
Kinetics of Human Hemopoietic Cells after In Vivo Administration of Granulocyte-Macrophage Colony-stimulating Factor
}

\author{
Massimo Aglietta, Wanda Piacibello, Fiorella Sanavio, Alessandra Stacchini, Franco Aprá, Marina Schena, Carlo Mossetti, \\ Flavio Carnino, Federico Caligaris-Cappio, and Felice Gavosto \\ Clinica Medica A, Dipartimento di Scienze Biomediche ed Oncologia Umana dell'Universitá; and Divisione di Ginecologia, \\ Ospedale S. Anna, 10126 Torino, Italy
}

\begin{abstract}
The kinetic changes induced by granulocyte-macrophage colony-stimulating factor (GM-CSF) on hemopoietic cells were assessed in physiological conditions by administering GMCSF (8 $\mu \mathrm{g} / \mathrm{kg}$ per d) for $3 \mathrm{~d}$ to nine patients with solid tumors and normal bone marrow (BM), before chemotherapy. GMCSF increased the number of circulating granulocytes and monocytes; platelets, erythrocytes, lymphocyte number, and subsets were unmodified. GM-CSF increased the percentage of BM S phase BFU-E (from $32 \pm 7$ to $79 \pm 16 \%$ ), day 14 colony-forming unit granulocyte-macrophage (CFU-GM) (from $43 \pm 20$ to $82 \pm 11 \%$ ) and day 7 CFU-GM (from $41 \pm 14$ to $56 \pm 20 \%$ ). The percentage of $B M$ myeloblasts, promyelocytes, and myelocytes in $S$ phase increased from $26 \pm 14$ to $41 \pm 6 \%$, and that of erythroblasts increased from $25 \pm 12$ to $30 \pm 12 \%$. This suggests that GM-CSF activates both erythroid and granulomonopoietic progenitors but that, among the morphologically recognizable BM precursors, only the granulomonopoietic lineage is a direct target of the molecule. GM-CSF increased the birth rate of cycling cells from 1.3 to 3.4 cells $\% / h$ and decreased the duration of the $S$ phase from 14.3 to 9.1 $h$ and the cell cycle time from 86 to $26 \mathrm{~h}$. After treatment discontinuation, the number of circulating granulocytes and monocytes rapidly fell. The proportion of $S$ phase BM cells dropped to values lower than pretreatment levels, suggesting a period of relative refractoriness to cell cycle-active antineoplastic agents.
\end{abstract}

\section{Introduction}

Human granulocyte-macrophage colony-stimulating factor $(\mathrm{GM}-\mathrm{CSF})^{1}$ is a single-chain polypeptide active in vitro on

\footnotetext{
Address reprint requests to Dr. Felice Gavosto, Clinica Medica A, Via Genova 3, 10126 Torino, Italy.

Received for publication 3 August 1988 and in revised form 16 September 1988.
}

1. Abbreviations used in this paper: BM, bone marrow; BPA, burstpromoting activity; BrdU, bromodeoxyuridine; CFU-GM, colonyforming units, granulocyte-macrophage; FITC, fluorescein isothiocyanate; FH, Ficoll Hypaque; GM-CSF, granulocyte-macrophage colony-stimulating factor; $\left[{ }^{3} \mathrm{H}\right] \mathrm{TdR}$, tritiated thymidine; IMDM, Iscove's modified Dulbecco's medium; $K_{\mathrm{b}}$, birth rate; $K_{\mathrm{in}-\mathrm{s}}$, number of cells entering the $S$ phase per unit of time; $K_{\text {out-S }}$, number of cells leaving the $\mathrm{S}$ phase per unit of time; $\mathrm{LI}$, labeling index; $\mathrm{R}$, rabbit; $\mathrm{S}$, swine; $T_{\mathrm{c}}$, cell cycle time; $T_{\mathrm{s}}$, duration of $\mathrm{S}$ phase; TRITC, tetraethylrhodamine.

J. Clin. Invest.

(c) The American Society for Clinical Investigation, Inc.

$0021-9738 / 89 / 02 / 0551 / 07 \$ 2.00$

Volume 83, February 1989, 551-557 hemopoietic precursors, mature granulocytes, and monocytes (1-10). Alone or in combination with other hemopoietins, it stimulates the proliferation and differentiation of multipotent and lineage-committed erythroid (BFU-E), granulomonocytic (CFU-GM) and megakaryocytic progenitors (1-6).

Recent evidence also suggests an in vivo action of GM-CSF both in nonhuman primates and in humans (11-15). The treatment with GM-CSF has increased the number of circulating granulocytes and monocytes in patients with AIDS and myelodisplastic syndromes and has shortened the leukopenic period in patients undergoing autologous bone marrow transplantation (13-15). An increase in the number of circulating progenitors and in the percentage of $S$ phase bone marrow (BM) CFU-GM after GM-CSF administration has also been observed $(16,17)$. GM-CSF effects on platelet and erythocyte production and on circulating lymphocytes are less defined. These uncertainties may simply reflect the difficulty of assessing the response of hemopoietic cells to GM-CSF in subjects with already damaged hemopoiesis and demonstrate the importance of thoroughly exploring its activity in physiological conditions. Determining which cells are the target of the molecule and how and to what extent their proliferation is influenced in vivo would allow proper planning of therapeutic trials with GM-CSF.

In this paper we have investigated the cellular composition and the kinetic features of peripheral blood (PB) and $B M$ in nine patients with solid tumors and normal BM treated for $3 \mathrm{~d}$ with GM-CSF $(8 \mu \mathrm{g} / \mathrm{kg}$ per d) before chemotherapy.

We confirm that GM-CSF is in vivo a powerful stimulator of myelopoiesis and we add three new observations. First, GM-CSF delivers a striking proliferative signal to BM-committed progenitors CFU-GM and BFU-E, whereas its effect on morphologically identifiable precursors (amplification compartment) is predominantly restricted to the granulopoietic lineage. Second, GM-CSF shortens the cell cycle time $\left(T_{\mathrm{c}}\right)$ and the duration of $\mathrm{S}$ phase $\left(T_{\mathrm{s}}\right)$ of BM cycling cells and more than doubles their birth rate $\left(K_{\mathrm{b}}\right)$. Third, after discontinuation of GM-CSF, the BM-proliferative activity drops rapidly to values lower than pretreatment levels. These data may provide the basis for a more rational and kinetically interrelated administration of cell cycle-specific drugs and GM-CSF in cancer protocols.

\section{Methods}

\section{Patients}

Patients with histologically proven neoplasia not involving the myeloid system and normal BM participated in the study. Each patient gave written informed consent according to the Helsinki declaration. All but two patients had $\mathrm{Hb}$ levels $>12 \mathrm{~g} \%$. Two patients had lower levels of $\mathrm{Hb}$ ( 8.8 and $8.9 \mathrm{~g} \%$ ) due to recent surgical procedures. Nevertheless, the morphological evaluation of BM never revealed signs of abnormal 
myelopoiesis or erythropoiesis. All patients had normal leukocyte and platelet counts, normal liver and kidney function and no signs of abnormalities except those related to the neoplasia. Eight patients with solid tumors were studied at the time of primary diagnosis and one at relapse for a non-Hodgkin's lymphoma. No concomitant treatments with corticosteroids, sulphonamides, $\mathrm{H} 2$ antagonists, nonsteroidal antiinflammatory drugs, or lithium were administered.

\section{GM-CSF}

GM-CSF, supplied by Sandoz Ltd. (Basel, Switzerland) in purified lyophilized form, was obtained by a recombinant DNA technique and was secreted by a mammalian cell system (3).

\section{Study design}

GM-CSF was administered to eight patients at the dose of $8 \mu \mathrm{g} / \mathrm{kg}$ per d for $3 \mathrm{~d}$ by continuous intravenous infusion. A ninth patient received the drug by subcutaneous route ( $4 \mu \mathrm{g} / \mathrm{kg}$ per $12 \mathrm{~h}$ for six times).

Before and during the course of the study, the patients were monitored daily by the recording of vital signs, physical examination, determination of the complete blood count with differential (including neutrophil segmentation by the Arneth score), and reticulocyte counts.

A BM aspirate for morphological, immunological, kinetic, and in vitro culture studies was performed in all patients before and $3 \mathrm{~d}$ after starting the treatment. One or two additional BM aspirates were performed 1-4 d after discontinuing GM-CSF. At the time of the BM aspirate a sample of $15 \mathrm{ml}$ of $\mathrm{PB}$ was collected to evaluate the absolute number of circulating CFU-GM, their kinetic status and the distribution of lymphocyte subsets.

\section{Bone marrow morphology}

A differential morphological analysis was performed on Giemsastained slides of each BM aspirate. Myeloblasts, promyelocytes, myelocytes, and proerythroblasts, basophilic erythroblasts, and early polychromatophylic erythroblasts were considered the morphologically identifiable proliferating precursors belonging to the amplification compartment, respectively, of granulopoiesis and erythropoiesis.

The differentiation index of granulopoietic cells was calculated as a ratio between myelocytes + metamyelocytes + granulocytes + monocytes/blasts + promyelocytes.

\section{Kinetic investigation of bone marrow-committed progenitors}

The fraction of CFU-GM and of BFU-E in DNA synthesis (S phase) was assessed by the suicide technique after exposure to high specific activity tritiated thymidine $\left(\left[{ }^{3} \mathrm{H}\right] \mathrm{Tdr}\right)$ before agar and methylcellulose cultures (18).

BM light-density fraction was collected after Ficoll Hypaque (FH) separation (Lymphoprep; Nyegaard, Oslo, Norway), washed three times and resuspended in $0.5 \mathrm{ml}$ of Iscove's modified Dulbecco's medium (IMDM; Flow Laboratories, Irvine, UK) + 10\% FCS (Flow Laboratories) at a concentration of $1 \times 10^{6}$ cells $/ \mathrm{ml}$. Five tubes were prepared and incubated with: medium (in duplicate), $0.5 \mathrm{mg} / \mathrm{ml}$ cold thymidine, $\left[{ }^{3} \mathrm{H}\right] \mathrm{Tdr}(100 \mu \mathrm{Ci} / \mathrm{ml} ; 20 \mathrm{Ci} / \mathrm{mM}$ sp act, Amersham International, Buckinghamshire, UK; in duplicate). After 30 min incubation at $37^{\circ} \mathrm{C}$ the reaction was stopped by the addition of $5 \mathrm{ml}$ ice-cold HBSS containing $0.5 \mathrm{mg} / \mathrm{ml}$ unlabeled thymidine. After three washes, the cells were resuspended in IMDM: CFU-GM and BFU-E cultures were prepared with standard procedure (19), seeding $1 \times 10^{5}$ cells/dish of the original cell suspension. For CFU-GM, $10 \%$ conditioned medium of the 5637 cell line was the source of CSFs. BFU-E were prepared in presence of $1.5 \mathrm{IU}$ erythropoietin (Toyobo, Osaka, Japan), 0.2 $\mathrm{mM}$ hemin and $10 \%$ human cord blood endothelium supernatant as source of burst-promoting activity (BPA).

After 7- and 14-d incubation periods, the number of colonies and bursts was evaluated by two independent investigators. The percentage of progenitors in the $\mathrm{S}$ phase of the cell cycle $\left(N_{\mathrm{s}}\right)$ was determined by applying the following formula: $N_{\mathrm{s}}=N_{\mathrm{c}}-N_{\mathrm{t}} / N_{\mathrm{c}}$, where $N_{\mathrm{c}}$ is the number of colonies or bursts in the controls and $N_{t}$ is the number of colonies or bursts in the samples treated with high dose $\left[{ }^{3} \mathrm{H}\right] \mathrm{Tdr}$.

\section{Kinetic investigation of bone marrow morphologically identifiable precursors cells (amplification compartment)}

(i) IN VITRO EVALUATION OF DNA-SYNTHESIZING CELLS (a) Bromodeoxyuridine ( $B r d U$ ) incorporation. The percentage of light-density BM cells synthesizing DNA was evaluated by adding 10 $\mu \mathrm{M}$ BrdU (Sigma Chemical Co., St. Louis, MO) to $1 \times 10^{6} \mathrm{FH}$-separated cells for $1 \mathrm{~h}$. Cytocentrifuge smears were stained in indirect immunofluorescence with a specific anti-BrdU antibody. (cat. no. 7580; Becton Dickinson \& Co., Mountain View, CA) (20).

(b) $\left[{ }^{3} H\right] T d r$ studies. To separately evaluate the proliferative activity of granulopoietic and erythropoietic morphologically identifiable precursors, autoradiographic studies with $\left[{ }^{3} \mathrm{H}\right] \mathrm{Tdr}$ were performed according to reference 21 .

BM samples, diluted with IMDM, were incubated at $37^{\circ} \mathrm{C}$ with 10 $\mu \mathrm{C} / \mathrm{ml}\left[{ }^{3} \mathrm{H}\right] \mathrm{Tdr}(5 \mathrm{Ci} / \mathrm{mM}$ sp act, Amersham International) for $1 \mathrm{~h}$. The slides were fixed with Carnoy methilic, washed repeatedly with water, and coated in the dark with nuclear track emulsion $\left(\mathrm{NTB}_{2}\right.$; Eastman Kodak, Rochester, NY). After 2-3 d of exposure, the slides were developed with Kodak D19 developer and stained with buffered Giemsa (pH 7.2). Only slides with a mean background less than 2 (i.e., the number of grains in the mean area occupied by a nucleus) were considered. All cells with more than six grains over the nucleus were considered positive; however, $>90 \%$ of positive cells in our preparations had $>20$ grains. The proportion of labelled cells was considered the labeling index (LI) of the population studied $(21,22)$.

(ii) IN VIVO EVALUATION OF KINETIC PARAMETERS

In vivo evaluation of kinetic parameters was performed with doublelabeling studies according to Raza et al. with modifications (23).

Three patients received a dose of $200 \mathrm{mg} / \mathrm{sqM}$ of BrdU in $50 \mathrm{ml}$ of $0.9 \%$ saline infused over $15 \mathrm{~min} .2 \mathrm{~h}$ after the midpoint of the infusion, a BM sample was collected in heparin and separated on FH. The whole procedure was performed at $4^{\circ} \mathrm{C}$. The light-density cells were incubated at $37^{\circ} \mathrm{C}$ for $1 \mathrm{~h}$ with $\left[{ }^{3} \mathrm{H}\right] \mathrm{Tdr}$, as described above. At the end of the incubation, slides were prepared with a cytocentrifuge and processed for evaluation of the percentage of BrdU+ cells, $\left[{ }^{3} \mathrm{H}\right] \mathrm{Tdr}+$ cells, or $\mathrm{BrdU}+/{ }^{3} \mathrm{HTdr}+$ double-labeled cells, as described above.

The following kinetic parameters were calculated. (a) $T_{\mathrm{s}}$ (length of the $\mathrm{S}$ phase of the cell cycle), using the formula: $T_{\mathrm{s}}=\left(\mathrm{DL}+\left[{ }^{3} \mathrm{H}\right] \mathrm{Tdr}\right)$ $\times 2 / \mathrm{BrdU}$, where $\mathrm{DL}$ is the number of double-labeled cells, $\left[{ }^{3} \mathrm{H}\right] \mathrm{Tdr}$ and $\mathrm{BrdU}$ are the number of cells that were $\left[{ }^{3} \mathrm{H}\right] \mathrm{Tdr}$ or $\mathrm{BrdU}$ positive, respectively; 2 is the time in hours that elapsed between the midpoint of BrdU infusion and the BM aspirate.

(b) $T_{\mathrm{c}}$ (length of the cell cycle), using the formula $T_{\mathrm{c}}=T_{\mathrm{s}} / \mathrm{LI}$, where $\mathrm{LI}$ is the LI of the amplification compartment, assuming a growth fraction of one, as only the proliferating compartment was studied.

(c) $K_{\mathrm{in}-\mathrm{S}}$ (number of cells entering the $\mathrm{S}$ phase per unit of time) and $K_{\text {out-S }}$ (number of cells leaving the $S$ phase per unit of time) with the formulas: $K_{\text {in-s }}=\%\left[{ }^{3} \mathrm{H}\right] \mathrm{Tdr}$ cells $/ 2 ; K_{\text {out-s }}=\% \mathrm{BrdU}$ cells $/ 2$, where 2 is the time in hours elapsed between the mid of BrdU infusion and the BM aspirate.

(d) $K_{\mathrm{b}}$ (birth rate = percent of cells produced per hour) with the formula: $\left(K_{\text {in-s }}+K_{\text {out-s }}\right) / 2$.

\section{Peripheral blood cells}

The morphology of peripheral mature cells was studied on Giemsastained cells. The segmentation of neutrophils (Arneth score) was determined by calculating the mean number of lobes in 100 neutrophils. The fraction of CFU-GM in S phase was assessed as above starting from a cell preparation of $1.8 \times 10^{6}$ cells $/ \mathrm{ml}$, working with $1 \mathrm{ml}$ and seeding $6 \times 10^{5}$ cells/dish of the original cell suspension.

Lymphocyte characterization. The possible influence of in vivo administration of GM-CSF on the lymphoid compartment has been studied in six patients, investigating whether GM-CSF might $(a)$ increase the percentage of BM lymphoid precursors (i.e., the cells ex- 
pressing CD10 [CALLA] antigen and the nuclear terminal deoxinucleotidyl transferase [TdT] enzyme); $(b)$ modify the subset distribution of $\mathrm{T}$ and $\mathrm{B}$ cell populations in the peripheral blood; $(c)$ activate circulating $\mathrm{T}$ cells; $(d)$ increase the proportion of proliferating lymphocytes in the peripheral blood.

$\mathrm{PB}$ and BM mononuclear cells were obtained by $\mathrm{FH}$ separation and washed twice. Cytocentrifuge smears $\left(2.5 \times 10^{5}\right.$ cells/slide $)$ were air dried, fixed, and stained with $\mathrm{Ab}$ combinations as previously described (24).

Rabbit (R) antisera to human IgM conjugated with tetraethylrhodamine (TRITC) (cat. no. R-152; Dakopatts, Glostrup, Denmark) were used in direct immunofluorescence (IF). R-anti-TdT (cat. no. 004; Supertech Inc., Bethesda, MD) was used to detect the nuclear enzyme TdT in indirect IF assay with swine (S) anti-R-Ig-TRITC second layer. The MAbs used included CD1 (cat. no. 7340, Leu6; Becton-Dickinson \& Co.), CD4 (cat. no. 6320, Leu3; Becton-Dickinson \& Co.), CD8 (cat. no. 7500, Leu2; Becton-Dickinson \& Co.), CD25 (cat. no. 7640, IL2 receptor; Becton-Dickinson \& Co.), and Leu7 (cat. no. 7390; Becton-Dickinson \& Co.). Ki67 (kind gift of Prof. H. Stein, Berlin, FRG), a MAb that detects a nuclear antigen expressed by cells in $G 1, S, G 2$, and $M$ phase of the cell cycle, but absent in $G_{0}(25)$ was used to estimate the growth fraction of circulating lymphocytes. The $M A b$ reactivity was revealed with second layer $\mathrm{R}$-anti-M-Ig conjugated with fluorescein isothiocyanate (FITC, cat. no. F 261; Dakopatts).

\section{Results}

\section{Peripheral blood changes induced by GM-CSF}

As shown in Table I, the absolute number of granulocytes and monocytes was increased three to fourfold during the treatment with GM-CSF. Platelets did not change and reticulocytes increased only marginally. The increase in granulocytes (both neutrophils and eosinophils) was accompanied by a marked shift to the left, as witnessed by the Arneth score. Moreover, sporadic myelocytes and metamyelocytes appeared in the PB, their number being higher shortly after discontinuation of treatment.

Table II shows the absolute number of day 14 CFU-GM circulating in the PB at various times of the study and their proportion in $\mathrm{S}$ phase. Some increase in the absolute number of circulating progenitors (from $144 \pm 96$ to $376 \pm 308$ CFU$\mathrm{GM} / \mathrm{ml}$ ) was evident at the end of treatment. This was observed in five of seven cases and marked patient to patient variations were evident. The percentage of S phase CFU-GM was only slightly increased by GM-CSF.
The absolute lymphocyte number did not change significantly. At time $0, \mathrm{CD} 3+$ cells were $69 \pm 7 \%, \mathrm{CD} 4+$ cells $45 \pm 8 \%, \mathrm{CD} 8+$ cells $24 \pm 9 \%$, Leu $7+$ cells $12 \pm 3 \%, \mathrm{SIgM}^{+}$cells $5 \pm 1 \%$. The proportions of $B$ and $T$ cells as well as $T$ cell subsets were unmodified during treatment. The proportion of PB T cells expressing the IL2 receptor (CD25+) was unchanged after the administration of GM-CSF $(<1 \%)$, suggesting that lymphocyte activation had not occurred. Likewise, the percentage of circulating lymphocytes reacting with Ki67 MAb $(0.7 \pm 0.2 \%)$ was unmodified by GM-CSF treatment.

\section{Bone marrow changes induced by GM-CSF}

(i) MORPHOLOGY

BM cell composition showed a marked increase in the proportion of immature cells and of the leuko erythrogenetic ratio. The differentiation index decreased during treatment (Table III).

The pretreatment value of $\mathrm{CD} 10+$ cells was $2.6 \pm 1 \%$ and of $\mathrm{TdT}+$ cells was $0.9 \pm 0.3 \%$. After treatment, CD10+ or TdT+ cells could barely be seen (one to two/slide, i.e., $1-2 / 2.5 \times 10^{5}$ cells) as the proportion of lymphoid cells in every cytospin was drastically reduced by the overwhelming majority of myeloid elements. No difference could be observed between the BM at day 3 and the BM obtained in the days (1-4) after discontinuation of GM-CSF.

\section{(ii) KINETICS OF COMMITTED PROGENITORS}

Table IV shows the percentage of BM CFU-GM (day 14 CFU-GM and their more mature progeny day 7 CFU-GM) and BFU-E in S phase (as determined by the $\left[{ }^{3} \mathrm{H}\right] \mathrm{Tdr}$ suicide technique) at various time intervals. GM-CSF induced a marked and significant increase in day 14 CFU-GM (from $43 \pm 20$ to $82 \pm 11 \%$ ) and BFU-E (from $32 \pm 7$ to $79 \pm 10 \%$ ) in S phase and to a lesser extent of day 7 CFU-GM (from $41 \pm 14$ to $56 \pm 20 \%)$.

(iii) KINETICS OF MORPHOLOGICALLY IDENTIFIABLE PRECURSORS (AMPLIFICATION COMPARTMENT)

(a) Kinetics in vitro. The proportion of low density cells (i.e., a population enriched in early myeloid cells) in S phase (as determined by BrdU incorporation) rose from $19 \pm 4$ to $32 \pm 7 \%$ (Table IV). The autoradiographic analysis allowed separate evaluation of the proliferation of early granulopoietic and early erythroid cells induced by GM-CSF. The overall percent-

Table I. Modifications of Peripheral Blood Parameters Induced by GM-CSF Treatment (3-d Continuous Intravenous Infusion) and its Discontinuation

\begin{tabular}{|c|c|c|c|c|c|c|c|c|}
\hline & \multicolumn{8}{|c|}{ Day of study } \\
\hline & 0 & 1 & 2 & 3 & 4 & 5 & 6 & 7 \\
\hline $\mathrm{WBC}\left(\times 10^{9} /\right.$ liter $)$ & $7.9 \pm 4.0$ & $15.2 \pm 5.7^{*}$ & $19.6 \pm 7.6^{*}$ & $20 \pm 7.5^{*}$ & $11.8 \pm 6.1$ & $9.9 \pm 5$ & $9.0 \pm 4$ & $8.4 \pm 3.2$ \\
\hline Neutrophil $\left(\times 10^{9} /\right.$ liter $)$ & $5.7 \pm 3.0$ & $12.6 \pm 7.2^{\ddagger}$ & $16.5 \pm 7.2^{*}$ & $16.4 \pm 6.8^{*}$ & $8.4 \pm 5.3$ & $6.7 \pm 4.2$ & $6.1 \pm 3.6$ & $5.9 \pm 3.2$ \\
\hline $\operatorname{Eosin}\left(\times 10^{9} /\right.$ liter $)$ & $0.18 \pm 0.15$ & $0.49 \pm 0.52$ & $0.80 \pm 0.42^{*}$ & $0.91 \pm 0.44^{*}$ & $0.78 \pm 0.63^{\ddagger}$ & $0.30 \pm 0.25$ & $0.33 \pm 0.27$ & $0.26 \pm 0.15$ \\
\hline Lymphocytes $\left(\times 10^{9} /\right.$ liter $)$ & $1.8 \pm 0.9$ & $1.4 \pm 0.5$ & $1.5 \pm 0.8$ & $1.8 \pm 0.6$ & $1.9 \pm 0.6$ & $1.8 \pm 0.7$ & $1.8 \pm 0.5$ & $1.8 \pm 0.4$ \\
\hline Monocytes $\left(\times 10^{9} /\right.$ liter $)$ & $0.21 \pm 0.08$ & $0.49 \pm 0.21^{*}$ & $0.54 \pm 0.16^{*}$ & $0.69 \pm 0.43^{*}$ & $0.59 \pm 0.24^{*}$ & $0.46 \pm 0.25^{\ddagger}$ & $0.46 \pm 0.22^{\ddagger}$ & $0.39 \pm 0.20^{\ddagger}$ \\
\hline $\mathrm{Hb} \mathrm{g} \%$ & $11.4 \pm 1.8$ & $10.7 \pm 1.5$ & $11.0 \pm 1.8$ & $11.0 \pm 1.8$ & $10.9 \pm 1.9$ & $10.9 \pm 1.8$ & $10.8 \pm 1.8$ & $10.9 \pm 1.7$ \\
\hline Reticulocytes $\left(\times 10^{9} /\right.$ liter $)$ & $90 \pm 30$ & $93 \pm 40$ & $106 \pm 39$ & $114 \pm 42$ & $111 \pm 50$ & $90 \pm 37$ & $92 \pm 23$ & $94 \pm 28$ \\
\hline Plat $\left(\times 10^{9} /\right.$ liter $)$ & $288 \pm 87$ & $290 \pm 95$ & $294 \pm 80$ & $295 \pm 82$ & $286 \pm 82$ & $306 \pm 85$ & $315 \pm 83$ & $312 \pm 76$ \\
\hline Neutrophil segmentation & $2.10 \pm 0.13$ & $1.86 \pm 0.20^{\ddagger}$ & $1.52 \pm 0.13^{*}$ & $1.40 \pm 0.12^{*}$ & $1.50 \pm 0.18^{*}$ & $1.80 \pm 0.16^{\ddagger}$ & $1.98 \pm 0.14$ & $2.02 \pm 0.17$ \\
\hline
\end{tabular}

Average results $\pm \mathrm{SD}$ of the data obtained from eight patients. Plat, platelets. ${ }^{*} P<0.01$ (compared with data at day 0 ); $\quad{ }^{\ddagger} P<0.05$. 
Table II. Modifications of the Absolute Number of Circulating CFU-GM/ml and of their Proliferative Status Induced by GM-CSF Treatment (3-d Continuous Intravenous Infusion) and its Discontinuation

\begin{tabular}{lcccccc}
\hline & \multicolumn{5}{c}{ Day of study } \\
\cline { 2 - 7 } & $0(7)$ & $3(7)$ & $4(3)$ & $5(4)$ & $6(5)$ & $7(2)$ \\
\hline Day 14 CFU-GM/ml & $144 \pm 96$ & $376 \pm 308$ & $286 \pm 390$ & $360 \pm 414$ & $444 \pm 360$ & $638 \pm 497^{*}$ \\
$\%$ Day 14 CFU-GM in S phase & $11 \pm 7$ & $16 \pm 6$ & $25 \pm 18$ & $26 \pm 16$ & $22 \pm 10$ & $23 \pm 8$ \\
\hline
\end{tabular}

Average results \pm SD of different experiments ( $n$ of samples are in parentheses). Mean \pm SD of the absolute number of CFU-GM per milliliter of peripheral blood. Mean \pm SD of the percentage of day 14 CFU-GM killed by $\left[{ }^{3} \mathrm{H}\right]-\mathrm{TdR}$ suicide technique. ${ }^{*} P<0.05$ (compared with data at day 0).

age of early BM cells in $\mathrm{S}$ phase was significantly increased (from $26 \pm 8$ to $38 \pm 7 \%$ ) (Table IV). The proportion of early granulopoietic cells (myeloblasts, promyelocytes, and myelocytes) in $S$ phase rose from $26 \pm 16 \%$ to $41 \pm 6 \%$ and that of early erythroid cells (proerythroblasts, basophilic erythroblasts, early polichromatophilic erythroblasts) from $25 \pm 12$ to $30 \pm 12 \%$. These data indicate that GM-CSF acted predominantly on the granulopoietic lineage.

(b) Kinetics in vivo. From the above data, GM-CSF induced stimulation of the proliferation of BM cells was evident. Nevertheless its magnitude could not be calculated as variations in cell cycle times remained unknown. To partially obviate these kinetic problems, a double in vivo/in vitro technique was used to calculate $T_{\mathrm{s}}, T_{\mathrm{c}}, K_{\mathrm{in}-\mathrm{S}}$ and $K_{\text {out-s }}$ (Table V). Three patients entered this study: two received GM-CSF intravenously and one subcutaneously. Changes in PB and BM parameters after subcutaneous treatment were similar to those observed in the patients treated by intravenous route (data not shown); thus, the data are analyzed together. GM-CSF shortened $T_{\mathrm{s}}$ from $14.3 \pm 4.7$ to $9.1 \pm 1.5 \mathrm{~h}$ and reduced to even a greater extent the $T_{\mathrm{c}}$ of the cycling population (from $86 \pm 18$ to $26 \pm 4 \mathrm{~h}$ ). The $K_{\text {in-s }}$ was increased from 1.4 to 3.0 cells\%/h by the treatment; the $K_{\text {out-s }}$ from 1.2 to 3.8 cells\%/h. The similarity of $K_{\text {in-s }}$ and $K_{\text {out-s }}$ suggests that no significant cell loss took place during $\mathrm{S}$ and allows therefore calculations of the $K_{\mathrm{in}-\mathrm{S}}$ and the $K_{\text {out-s }}$ together to determine the $K_{\mathrm{b}}$. This rose from 1.3 to 3.4 cells $\% / h$. Similar results (not shown) were obtained using the formula $K_{\mathrm{b}}=\mathrm{LI} / T_{\mathrm{s}}$. These findings indicate that GM-CSF more than doubled the overall production of cells per hour.

\section{Effects of GM-CSF discontinuation}

When treatment was discontinued, there was a rapid fall in the number of granulocytes and a slower decline of monocytes
(Table I). The differentiation index, which had been decreased by the treatment, rapidly reached levels equal or even higher than the initial ones (Table III).

The proportion of BM cycling cells rapidly decreased. 48-96 $\mathrm{h}$ after treatment, in the presence of a still hyperplastic BM (as inferred by the persistence of a decreased proportion of lymphocytes) the percentage of BrdU+ cells was lower than pretreatment values ( $13 \pm 5 \%$ at day 6 ) (Table IV).

Autoradiographic analysis revealed that three days after GM-CSF discontinuation, the proportion of morphologically identifiable granulopoietic precursors in $\mathrm{S}$ phase dropped to $18 \pm 6 \%$. Concomitantly, the proportion of progenitors in $S$ phase dropped to values substantially lower than the initial ones (Table IV).

\section{Discussion}

In this paper, we report the effects of GM-CSF administered in vivo to subjects with normal bone marrow. The results can be divided into two parts. First, the modifications of PB and BM components and of their kinetics during GM-CSF treatment. Second, the analysis of the feedback phenomena that take place after discontinuing GM-CSF.

GM-CSF markedly stimulates the production of cells of the granulomonocytic pathway. Conceivably, the early rise of peripheral mature granulocytes and monocytes could depend on the release in the circulation of the marginal pool. However, our in vivo studies demonstrate that the BM production of immature granulopoietic cells is definitely an early and very active event after GM-CSF treatment. The pool of committed progenitors and morphologically identifiable granulopoietic precursors in $\mathbf{S}$ phase is significantly expanded and the leukoerythrogenetic ratio is markedly increased. GM-CSF is thus able to stimulate the proliferation of the entire granulopoietic

Table III. Modifications of Some Bone Marrow Parameters Induced by GM-CSF Treatment (3-d Continuous Intravenous Infusion) and its Discontinuation

\begin{tabular}{|c|c|c|c|c|c|c|}
\hline & \multicolumn{6}{|c|}{ Day of study } \\
\hline & $0(8)$ & $3(8)$ & $4(3)$ & $5(4)$ & $6(5)$ & $7(2)$ \\
\hline Leukoerythrogenetic ratio & $1.2 \pm 0.2$ & $2.5 \pm 1^{*}$ & $2.2 \pm 1.4^{\ddagger}$ & $2.2 \pm 0.9^{\ddagger}$ & $1.8 \pm 0.7^{\ddagger}$ & $1.9 \pm 0.4^{\ddagger}$ \\
\hline Differentiation index & $32 \pm 14$ & $17 \pm 10^{\ddagger}$ & $13 \pm 4^{\ddagger}$ & $31 \pm 15$ & $52 \pm 27$ & $39 \pm 37$ \\
\hline \% Lymphocytes & $15.1 \pm 5.8$ & $8.5 \pm 2 *$ & $8.7 \pm 2^{\ddagger}$ & $8.1 \pm 2^{\ddagger}$ & $9.4 \pm 3.2^{\ddagger}$ & $8.3 \pm 2$ \\
\hline
\end{tabular}

Average results \pm SD of different experiments ( $n$ of samples are in parentheses). $\quad * P<0.01$ (compared with data at day 0 ); $\quad$ ( $P<0.05$. 
Table IV. Modification of the Percentage of Different BM Cell Populations in S Phase Induced by GM-CSF Treatment (3 d Continuous Intravenous Infusion), and its Discontinuation

\begin{tabular}{|c|c|c|c|c|c|c|}
\hline & \multicolumn{6}{|c|}{ Day of study } \\
\hline & $0(7)$ & $3(7)$ & $4(3)$ & $5(4)$ & $6(5)$ & $7(2)$ \\
\hline BFU-E & $32 \pm 7$ & $79 \pm 16^{*}$ & $50 \pm 10$ & $27 \pm 7$ & $19 \pm 10^{\ddagger}$ & $23 \pm 12$ \\
\hline Day 14 CFU-GM & $43 \pm 20$ & $82 \pm 11^{*}$ & $44 \pm 13$ & $33 \pm 7$ & $34 \pm 10$ & $42 \pm 4$ \\
\hline Day 7 CFU-GM & $41 \pm 14$ & $56 \pm 20$ & $38 \pm 20$ & $27 \pm 6$ & $21 \pm 10^{\ddagger}$ & $30 \pm 2$ \\
\hline Low density cells & $19 \pm 4$ & $32 \pm 7^{*}$ & $17 \pm 2$ & $12 \pm 2$ & $13 \pm 5^{\ddagger}$ & $13 \pm 4$ \\
\hline Early BM cell & $26 \pm 8$ & $38 \pm 7^{\ddagger}$ & $27 \pm 5$ & $25 \pm 6$ & $20 \pm 8$ & $20 \pm 6$ \\
\hline Early erythroid cells & $25 \pm 12$ & $30 \pm 12$ & $29 \pm 13$ & $27 \pm 9$ & $30 \pm 15$ & $27 \pm 10$ \\
\hline Early granulopoietic cells & $26 \pm 14$ & $41 \pm 6^{\ddagger}$ & $25 \pm 6$ & $23 \pm 3$ & $18 \pm 6$ & $17 \pm 2$ \\
\hline
\end{tabular}

For the different methods of estimation of the percentage of $\mathrm{S}$ phase cells see text. Average results \pm SD of different experiments $(n$ of samples are in parentheses). ${ }^{*} P<0.01$ (compared with data at day 0 ); ${ }^{\ddagger} P<0.05$.

line because it acts both on committed progenitors and on the compartment of amplification precursors.

The in vivo effect of GM-CSF on the erythroid compartment is different and shows an interesting discrepancy when compared with the effect on granulopoiesis. The percentage of BFU-E in the $S$ phase is significantly increased, whereas the proportion of DNA-synthesizing erythroblasts changes only marginally and the absolute number of reticulocytes is basically unmodified. These in vivo data, in accordance with in vitro observations suggesting a BPA activity of GM-CSF (1-6), indicate that GM-CSF acts predominantly on early erythroid progenitors and that the stimulation of BFU-E proliferation induced by GM-CSF is not sufficient per se to significantly enhance the production of erythrocytes. This implies that the proliferative effect exerted by GM-CSF on BFU-E can be brought to its final result only by the concomitant action of other hemopoietins. The most likely candidate to this role is erythropoietin, as witnessed by the data of Donahue et al. who observed a GM-CSF-induced reticulocytosis only in anemic primates with high erythropoietin levels (11).

The granulopoietic activity of GM-CSF is accomplished through important kinetic modifications that involve both committed progenitors and the morphologically identifiable cells that form the BM amplification compartment. First,

Table V. Effect of GM-CSF Treatment on BM Cell Kinetics

\begin{tabular}{lcc}
\hline & \multicolumn{2}{c}{ Day of study } \\
\cline { 2 - 3 } & 0 & 3 \\
\hline$K_{\text {in }}-\mathrm{S}$ & $1.4 \pm 0.45$ & $3.0 \pm 1^{*}$ \\
$K_{\text {out }}-\mathrm{S}$ & $1.2 \pm 0.25$ & $3.8 \pm 0.5^{\ddagger}$ \\
$T_{\mathrm{s}}$ & $14.3 \pm 4.7$ & $9.1 \pm 1.5$ \\
$T_{\mathrm{c}}$ & $86 \pm 18$ & $26 \pm 4^{\ddagger}$
\end{tabular}

$K_{\text {in }}-\mathrm{S}$, flux of BM cells into the S phase of the cycle (\% of cells $/ \mathrm{h}$ ); $K_{\text {out }}-\mathrm{S}$, flux out of the $\mathrm{S}$ phase (\% of cells/h); $T_{\mathrm{s}}$, length of the $\mathrm{S}$ phase (h); $T_{\mathrm{c}}$, length of the cell cycle $(\mathrm{h})$.

All these parameters were calculated on FH-separated BM cells. Average results of three patients (two receiving continuous intravenous infusion and one subcutaneous injection of GM-CSF).

${ }^{*} P<0.05 ;{ }^{\ddagger} P<0.01$ (compared with data at day 0 ).
GM-CSF increases the entrance of cells into the $S$ phase of cell cycle. Second, it shortens drastically the $T_{\mathrm{c}}$ of cycling cells and, to a lesser extent, also their mean $T_{\mathrm{s}}$. Third, it increases significantly the number of cells that enter the cycle/unit of time $\left(K_{\mathrm{b}}\right)$. These data, together with the $\left[{ }^{3} \mathrm{H}\right] \mathrm{Td}$ suicide results on $\mathrm{BM}$ progenitors, lead to the relevant information that normally the committed progenitors and the amplification compartment of the BM are not proliferating at their possible maximal rate. Hence a reservoir capacity is present also in these populations and not only at the pluripotent stem cell level. This reservoir capacity can be exploited through two different mechanisms. One is the recruitment into cycle of temporarily out-of-cycle precursors, the other is the drastic shortening of the cycle time. The first could be the principal mechanism used by stem cell compartments to increase their own production rate and may well apply to the compartment of CFU-GM and BFU-E progenitors. The high percentage of progenitors killed by high-dose $\left[{ }^{3} \mathrm{H}\right] \mathrm{Tdr}$ suggests that almost all progenitors are entering into cycle as a consequence of GMCSF treatment. The second mechanism can account for the full realization of the reservoir capacity of BM morphologically identifiable precursors. The $K_{\text {in }}$ plus the production of cells into the compartment itself can be assumed to be equivalent to the $K_{\text {out }}$ even at time 0 (before administration of GM-CSF). This argues against the possibility that a substantial proportion of cells might move out of cycle during the transit through this compartment.

The absolute number of circulating CFU-GM increased in some patients during treatment (Table II). This increase was variable and less evident than reported by Socinski et al. after higher doses of GM-CSF for longer periods (16). The most relevant observation in $\mathrm{PB}$ as compared with $\mathrm{BM}$ is that the percentage of circulating progenitors in $S$ phase was only marginally modified by GM-CSF treatment, suggesting that also in a stress situation, normal CFU-GM need the BM environment to actively proliferate.

The absolute number of lymphocytes and their precursors, as well as the distribution of circulating lymphocyte subsets, did not change during treatment. Also activation antigens were not observed on the surface of PB lymphocytes, whose proliferative activity was not increased. These observations seem to rule out a direct action of GM-CSF on lymphocytes. The moderate lymphocytosis observed by Groopman et al. in AIDS 
patients treated with GM-CSF for a longer period (14 d) (13) might be ascribed to an indirect action of the molecule (i.e., monokine release).

A rapid fall to normal values in the number of neutrophils and eosinophils followed discontinuation of treatment. The slower decline in the number of monocytes probably reflects their longer half life. BM proliferation, too, dropped rapidly, and reached values somewhat lower than those observed before starting the treatment. Three explanations for this phenomenon are possible. First, inhibitory substances (i.e., acidic isoferritins, prostaglandins $\mathrm{E}$, lactoferrin) (26) whose action is no longer counteracted by pharmacologic levels of GM-CSF might slow the proliferation of cells. Second, the endogenous production of GM-CSF (and perhaps of other hemopoietic growth factors interacting with GM-CSF) might drop to values lower than the initial ones. Third, GM-CSF receptors might be downregulated on target cells. Whatever the biological reason for this slowing of proliferative activity, it appears likely that the 48-96 $\mathrm{h}$ after discontinuing the treatment with GM-CSF represent a period of partial refractoriness of $\mathrm{BM}$ cells to the cytoreductive effect of cell cycle-specific chemotherapeutic agents. This observation, supported by data in monkeys (12), suggests that a short treatment with GM-CSF followed by chemotherapy (and perhaps by additional GM-CSF administration after chemotherapy) might reduce the hemopoietic toxicity of antineoplastic treatments. However, the possibility has to be considered that GM-CSF, by stimulating proliferation and differentiation in the committed progenitor pool, might recruit more primitive progenitors into cycle to replenish the BFU-E and CFU-GM. If this happens, chemotherapy soon after GM-CSF treatment might interfere with the BM repopulation and lead to prolonged aplasia. Carefully controlled clinical trials are needed to address this issue and to evaluate the proper interplay between GM-CSF and cytotoxic drug administration.

\section{Acknowledgments}

We are indebted to Miss M. Rolando for secretarial assistance.

This work was supported with grants from Consiglio Nazionale delle Ricerche, Special Project Oncology, and from the Italian Association for Cancer Research.

\section{References}

1. Clark, S. C., and R. Kamen. 1987. The human hemopoietic colony stimulating factors. Science (Wash. DC). 236:1229-1237.

2. Sieff, C. A. 1987. Hemopoietic growth factors. J. Clin. Invest. 79:1549-1557.

3. Wong, G. G., J. S. Witek, P. A. Temple, K. M. Wilkens, A. C. Leary, D. P. Luxenberg, S. S. Jones, E. L. Brown, R. M. Kay, E. C. Orr, C. S. Shoemaker, D. W. Golde, R. J. Kaufman, R. M. Hewich, E. A. Wang, and S. C. Clark. 1985. Human GM-CSF: molecular cloning of the complementary DNA and purification of the natural and recombinant proteins. Science (Wash. DC). 288:810-815.

4. Sieff, C. A., S. G. Emerson, R. E. Donahue, D. G. Nathan, E. A. Wang, G. G. Wong, and S. C. Clark. 1985. Human recombinant granulocyte-macrophage colony stimulating factor: a multilineage hemopoietin. Science (Wash. DC). 230:1171-1173.

5. Kaushansky, K., P. J. O'Hara, K. Berkner, G. M. Segal, F. S. Hagen, and J. W. Adamson. 1986. Genomic cloning, characterization and multilineage growth promoting activity of human granulocyte macrophage colony stimulating factor. Proc. Natl. Acad. Sci. USA. 83:3101-3105.
6. Messner, H. A., K. Yamasaki, N. Jamal, M. M. Minden, Y. C. Yang, G. G. Wong, and S. C. Clark. 1987. Growth of human hemopoietic colonies in response to recombinant gibbon interleukin-3. Comparison with human recombinant granulocyte and granulocyte-macrophage colony stimulating factor. Proc. Natl. Acad. Sci. USA. 84:67656769.

7. Metcalf, D., C. G. Begley, G. R. Johnson, N. A. Nicola, M. A. Vadas, A. F. Lopez, D. J. Williams, G. G. Wong, S. C. Clark, and E. A. Wang. 1986. Biological properties in vitro of a recombinant granulocyte-macrophage colony stimulating factor. Blood. 67:37-45.

8. Weisbart, R. H., D. W. Golde, S. C. Clark, G. G. Wong, and J. C. Gasson. 1985. Human granulocyte-macrophage colony stimulating factor is a neutrophil activator. Nature (Lond.). 314:361-363.

9. Weiser, W. Y., A. Van Niel, S. C. Clark, J. R. David, and H. G. Remold. 1987. Recombinant human granulocyte-macrophage colony stimulating factor activates intracellular killing of Leishmania Donovani by human monocyte derived macrophages. J. Exp. Med. 166:1436-1446.

10. Fleischmann, J., D. W. Golde, R. H. Weisbart, and J. C. Gasson. 1986. Granulocyte-macrophage colony-stimulating factor enhances phagocytosis of bacteria by human neutrophils. Blood. 68:708-711.

11. Donahue, R. E., E. A. Wang, D. K. Stone, R. Kamen, G. G. Wong, P. K. Sehgal, D. G. Nathan, and S. C. Clark. 1986. Stimulation of hematopoiesis in primates by continuous infusion of recombinant GM-CSF. Nature (Lond.). 321:872-875.

12. Nienhuis, A. W., R. E. Donahue, S. Karlsson, S. C. Clark, B. Agricola, N. Antinoff, J. E. Pierce, P. Turner, W. F. Anderson, and D. G. Nathan. 1987. Recombinant human granulocyte-macrophage colony stimulating factor (GM-CSF) shortens the period of neutropenia after autologous bone marrow transplantation in a primate model. J. Clin. Invest. 80:573-577.

13. Groopman, J. E., R. T. Mitsuyasu, M. J. De Leo, D. H. Oette, and D. W. Golde. 1987. Effect of recombinant human granulocytemacrophage colony stimulating factor on myelopoiesis in the acquired immunodeficiency syndrome. N. Engl. J. Med. 317:593-598.

14. Vadhan-Raj, S., M. Keating, A. Le Maistre, W. N. Hittelman, K. Mc Credie, J. M. Trujillo, H. E. Broxmeyer, C. Henney, and J. U. Gutterman. 1987. Effects of recombinant human granulocyte-macrophage colony stimulating factor in patients with myelodysplastic syndromes. N. Engl. J. Med. 317:1545-1552.

15. Brandt, S. J., W. P. Peters, S. K. Atwater, J. Kurtzberg, M. J. Borowitz, R. B. Jones, E. J. Shpall, R. C. Bast, C. J. Gilbert, and D. H. Oette. 1988. Effect of recombinant human granulocyte-macrophage colony stimulating factor on hematopoietic reconstitution after high dose chemotherapy and autologous bone marrow transplantation. $N$. Engl. J. Med. 318:869-876.

16. Socinski, M. A., S. A. Cannistra, A. Elias, K. H. Antman, L. Schnipper, and J. D. Griffin. 1988. Granulocyte-macrophage colony stimulating factor expands the circulating hemopoietic progenitor cell compartment in man. Lancet. i:1194-1198.

17. Broxmeyer, H. E., S. Cooper, D. E. Williams, G. Hangoc, J. U. Gutterman, and S. Vadhan-Raj. 1988. Growth characteristics of marrow hemopoietic progenitor precursor cells from patients on a phase I clinical trial with purified recombinant human granulocyte-macrophage colony stimulating factor. Exp. Hematol. 16:594-603.

18. Lu, L., H. E. Broxmeyer, M. A. S. Moore, and H. T. Thaler. 1983. Association of cell cycle expression of Ia-like antigenic determinants on normal multipotential (CFU-GEMM) and erythroid (BFUE) progenitor cells with regulation in vitro by acidic isoferritins. Blood. 61:250-256.

19. Piacibello, W., L. Lu, M. Aglietta, B. Y. Rubin, S. Cooper, M. Watcher, F. Gavosto, and H. E. Broxmeyer. 1986. Human gamma interferon enhances release from phytohemoagglutinin stimulated T4+ lymphocytes of activities that stimulate colony formation by granulocyte-macrophage, erythroid, and multipotential progenitor cells. Blood. 68:1339-1347. 
20. Gratzner, H. G. 1982. Monoclonal antibody to 5-bromodeoxyuridine: a new reagent for detection of DNA replication. Science (Wash. DC). 218:474-475.

21. Gavosto, F., and A. Pileri. 1971. The cell cycle of cancer in man. In The Cell Cycle and Cancer. R. Baserga, editor. Marcel Dekker, Inc., New York. 99-129.

22. Cronkite, E. P. 1969. Kinetic of granulocytopoieis. In Human Tumor Cell Kinetics. S. Perry, editor. National Cancer Institute Monographs, Washington, DC. 51-62.

23. Raza, A., Y. Maheshwari, and H. D. Preisler. 1987. Differences in cell cycle characteristics among patients with acute nonlymphocytic leukemia. Blood. 69:1647-1653.
24. Caligaris-Cappio, F., L. Bergui, L. Tesio, G. Pizzolo, F. Malavasi, M. Chilosi, D. Campana, B. van Comp, and G. Janossy. 1985. Identification of malignant plasma cell precursors in the bone marrow of multiple myeloma. J. Clin. Invest. 76:1243-1251.

25. Gerdes, J., H. Lemke, H. Baisch, H. H. Wacker, U. Schwab, and H. Stein. 1984. Cell cycle analysis of a cell proliferation associated human nuclear antigen defined by the monoclonal antibody Ki67. $J$. Immunol. 133:1710-1716.

26. Aglietta, M., W. Piacibello, and F. Gavosto. 1987. Growth factors and growth inhibitors: their interaction in the regulation of human myelopoiesis. In The Inhibitors of Hematopoiesis. A. Najman, M. Guigon, N. C. Gorin, and J. Y. Mary, editors. J. Libbey-INSERM, Paris/London. 11-19. 